\title{
Plasma Calcitonin in Normal Man
}

\author{
DIFFERENCES BETWEEN MEN AND WOMEN
}

\author{
Hunter Heath III and Glen W. Sizemore, Mineral Research Laboratory, \\ Division of Endocrinology, Department of Medicine, Mayo Clinic and \\ Mayo Medical School, Rochester, Minnesota 55901
}

\begin{abstract}
A B S T RA C T We measured plasma calcitonin concentrations in healthy volunteers $(20$ men, ages $23-45$ yr, mean, $30 \mathrm{yr}$; 25 women, ages 21-46 yr, mean, 30 yr) with a radioimmunoassay capable of detecting $5 \mathrm{pg}$ of calcitonin $/ 500 \mu \mathrm{l}$ incubation volume, or $25 \mathrm{pg} / \mathrm{ml}$ of unextracted plasma. All subjects had 4-h calcium infusion ( $15 \mathrm{mg} \mathrm{Ca} / \mathrm{kg}$ ), and 24 subjects had intravenous pentagastrin injection $(0.5 \mu \mathrm{g} / \mathrm{kg})$ on separate days. Men had higher basal plasma immunoreactive calcitonin concentrations than women $(P<0.001)$ : mean, $49 \mathrm{pg} /$ $\mathrm{ml}$ (range, $<25-73$ ) and $31 \mathrm{pg} / \mathrm{ml}$ (range, $<25-51$ ), respectively. 18 of the 20 men $(90 \%)$ responded to induced hypercalcemia with increases in plasma immunoreactive calcitonin; only 14 of the 25 women $(56 \%)$ responded. In men, the mean increase of plasma immunoreactive calcitonin $\pm \mathrm{SE}$ was $58 \pm 9 \mathrm{pg} / \mathrm{ml}$, but for women was only $25 \pm 6 \mathrm{pg} / \mathrm{ml}$. 8 of 10 men $(80 \%)$ responded to pentagastrin with an increase of plasma immunoreactive calcitonin $>30 \mathrm{pg} / \mathrm{ml}$, compared with such a response in only 1 of 14 women (7\%). These differences of plasma immunoreactive calcitonin responses between the sexes were statistically significant (calcium infusion, $P<0.02$; pentagastrin, $P$ $<0.001)$. The physiologic importance of these observations is unknown, but we speculate that a lifelong, relative deficiency of calcitonin in some women could play a role in age- and sex-related bone loss, particularly during the estrogen-deficient postmenopausal years.
\end{abstract}

This work was presented in part at the 57th Annual Meeting of the Endocrine Society, New York, 18 June 1975.

Received for publication 28 August 1975 and in revised form 15 June 1977.

\section{INTRODUCTION}

Calcitonin $(\mathrm{CT})^{1}$ has been extensively studied in animals and in human subjects with medullary thyroid carcinoma, but the physiologic importance of the hormone in man has been questioned (1). Major impediments to the study of this problem have been the extremely low concentrations of immunoreactive CT in normal plasma, estimated to be as low as $5-50 \mathrm{pg} / \mathrm{ml}$ (2), and the general unavailability of radioimmunoassays for human CT with sufficient sensitivity to measure the low concentrations of the hormone in unextracted normal plasma (3-5). This report describes such a sensitive radioimmunoassay for human CT (detection limit $\leq 25 \mathrm{pg} / \mathrm{ml}$ plasma) and its application in healthy volunteers. The results of these studies show that women generally have lower basal and stimulated plasma immunoreactive calcitonin (iCT) concentrations than men, a finding possibly of great importance for understanding differences in bone metabolism between the sexes.

\section{METHODS}

\section{CT radioimmunoassay}

Production and characterization of anti-CT antiserum. Antiserum G 1701 was produced in collaboration with Dr. C. S. Anast by immunization of a goat with 35- to 50- $\mu \mathrm{g}$ doses of unconjugated synthetic human CT (Ciba-Geigy

\footnotetext{
${ }^{1}$ Abbreviations used in this paper: B/F, bound/free; $\Delta \mathrm{Ca}$, absolute increase of serum calcium from basal; CT, calcitonin; iCT, plasma immunoreactive calcitonin; $\Delta \mathrm{iCT}$, absolute increase of plasma immunoreactive calcitonin from basal.
} 
TABLE I

Effect of Plasma on CT Immunoreactivity during Storage at $-18^{\circ} \mathrm{C}$

\begin{tabular}{rcc}
\hline Time & iCT at $50 \%$ trace B/F & Potency \\
\hline$m o$ & $p g$ & $\%$ \\
0 & 17.6 & 100 \\
1 & 22.5 & 78 \\
12 & 32.0 & 55
\end{tabular}

Standards were made up in hypocalcitoninemic plasma and assayed immediately (time $=0$ ) and after 1 and 12 mo of storage. Results were compared to fresh standards $(<3 \mathrm{mo}$ old), made as described in the text, at the point of halfmaximal depression of the $B / F$ ratio.

Corp., Basel, Switzerland) in Freund's adjuvant, with simultaneous injection of pertussis vaccine i.m. A final antiserum dilution of 1:40,000 yielded "trace" bound/free (B/F) ratios of 0.6 to 0.8 . The sequence-specific antigenic recognition sites of the antiserum were determined with previously described methods (6), by comparing the ability of synthetic human CT and various synthetic peptide fragments (CibaGeigy) containing portions of the human CT amino acid sequence to inhibit the binding of ${ }^{131}$ I-labeled human CT to the antiserum. We assessed specificity of the antiserum by assaying up to $100 \mathrm{ng} /$ tube each of salmon CT, pentagastrin and porcine CT, secretin, and cholecystokininpancreozymin.

Assay procedure. Reagents were pipetted into $12 \times 75$ $\mathrm{mm}$ borosilicate glass tubes prechilled in an ice bath; preincubation and incubation stages took place on mechanical shakers (Eberbach Corp., Ann Arbor, Mich.) in a cold room $\left(4^{\circ} \mathrm{C}\right)$. The initial incubation volumes of $300 \mu \mathrm{l}$ included the following: $50-200 \mu \mathrm{l}$ of patient's or hypocalcitoninemic plasma; ${ }^{2} 0-150 \mu \mathrm{l}$ of assay diluent $(0.1 \mathrm{M}$ Tris, $\mathrm{pH} 7.8,5 \%$ Trasylol [Mobay Chemical Corp., FBA Pharmaceuticals, Inc., New York] and 5\% hypocalcitoninemic plasma); and $100 \mu \mathrm{l}$ of $\mathrm{G} 1701$ antiserum in diluent to make a preincubation dilution of $1: 24,000$ and a final dilution of 1:40,000. After a 4- to 7-day preincubation, we added $2,000 \mathrm{cpm}$ of ${ }^{131}$ I-labeled synthetic human CT tracer (6) in $200 \mu \mathrm{l}$ of assay diluent, and continued incubation at $4^{\circ} \mathrm{C}$ for 3 days. Quadruplicate control or no-antibody tubes and "trace" tubes (hypocalcitoninemic plasma in same volume as samples), used to determine "damage" $(<5 \%$ for $200-\mu l$ plasma additions) and trace or initial B/F ratios, surrounded groups of 20-25 sample tubes. Quadruplicate control and trace tubes (standard vehicle, $0.25 \%$ bovine serum albumin) surrounded 12 duplicate standards $(200-1.25 \mathrm{pg} / 100 \mu \mathrm{l})$ of synthetic human CT to produce the standard curve. CT standards were not diluted in plasma, for two reasons. First, Baylin et al. reported (7) that ${ }^{131}$ I-labeled human CT monomer was degraded in normal plasma by up to $44 \%$ in $5 \mathrm{~h}$, and that the rate of loss was accelerated with increasing hormone concentrations. Second, studies in our laboratory have shown that synthetic CT standards prepared in hypocalcitoninemic plasma undergo slow but progressive loss of immunoreactivity when stored at $-18^{\circ} \mathrm{C}$ (Table I).

\footnotetext{
${ }^{2}$ We screened 15 plasmas from totally thyroidectomized patients, which gave similar $B / F$ ratios in the assay, and used as "hypocalcitoninemic plasma" the one which $(a)$ gave the highest $B / F$ and $(b)$ came from a willing donor.
}

We separated bound from free ${ }^{131}$ I-labeled CT with dextran-coated charcoal (8). Separate tubes containing bound or free hormone were counted for $4 \mathrm{~min}$ in an automated gamma counter (Searle Analytic Inc., Des Plaines Ill.), linked to a PDP-8E digital computer (Digital Equipment Corp., Marlboro, Mass.). The computer calculated results as previously described $(8,9)$ : tubes containing $25-200 \mu \mathrm{l}$ of hypocalcitoninemic plasma (a volume equal to sample volume) yielded the trace or initial $\mathrm{B} / \mathrm{F}$ ratio (tracer binding in the absence of added CT), which was generally indistinguishable from the initial $B / F$ of the standard curve. The $B / F$ of sample tubes was computed, with correction for nonspecific binding, and expressed as a percent of trace $B / F$, which was then read from the standard curve. We next determined the -2 SD values for the sample trace tubes. Measurable CT was defined by inhibition of tracer binding by more than 2 SD from the mean trace value $(10,11)$. Therefore, for a sample to be judged to contain detectable $C T$, its $B / F$ ratio had to be lower than the mean trace or standard curve $B / F$ by $10-$ $15 \%$ or more.

Standard curves obtained by using synthetic human CT diluted in $0.25 \%$ bovine serum albumin or freshly prepared in hypocalcitoninemic plasma (100- or $200-\mu$ l additions) were superimposable. Stated differently, "recovery" of synthetic CT added to hypocalcitoninemic plasma and assayed immediately was $95.0 \pm 5.0 \%$ (mean $\pm \mathrm{SE}$ ). Trace $\mathrm{B} / \mathrm{F}$ ratios in the presence of varying amounts of hypocalcitoninemic plasma $(25-200 \mu \mathrm{l})$ differed by $<7 \%$ (Fig. 1). Intra- and interassay variability for the normal samples was $<20 \%$. All samples were assayed in duplicate $200-\mu$ l additions.

\section{$C T$ radioimmunoassay studies}

Two basal plasma samples were available for 15 subjects, three basal samples for 9 subjects, and a single sample for 21 subjects; each was analyzed for CT. All samples from one subject were analyzed in the same assay, and samples from male and female subjects were included in each assay. Samples of fasting plasma from. 14 subjects were assayed at various dilutions (200-, 150-, 100-, and 50- $\mu$ l samples); and four incubated at room temperature for studies of stability of immunoreactivity (12). Plasma from the 4th h of calcium infusion in four normal subjects and from two fasted patients with medullary thyroid carcinoma was likewise analyzed in multiple dilutions. These results were compared with $B / F$ ratios obtained with 25- to $200-\mu$ l sample additions of hypocalcitoninemic plasma to exclude nonspecific interference of plasma proteins with the immune reaction. We also assayed plasmas from 10 totally thyroidectomized fasted subjects, and before and during EDTA-induced hypocalcemia in a normal subject.

\section{Subjects and clinical studies}

The paid volunteers had had recent normal health examinations at the Mayo Clinic, felt well, and were taking no medications (particularly no oral contraceptives or estrogens). The 20 men were 23-45 yr old (mean, $30 \mathrm{yr}$ ) and the 25 women, all premenopausal, were 21-46 yr old (mean, $30 \mathrm{yr}$ ). All subjects gave informed consent to the studies, which were performed in the Clinical Research Center, with calcium and pentagastrin tests done in random order. All studies began after an overnight fast and before 10 a.m. Each subject underwent a 4-h calcium infusion (15 mg/kg elemental calcium as the gluconate) by Harvard infusion pump, with hourly venous blood sampling. On separate days each received pentagastrin (Peptavlon, Ayerst Laboratories, New York), $0.5 \mu \mathrm{g} / \mathrm{kg}$ in $0.9 \% \mathrm{NaCl}$, by rapid i.v. injection, with 


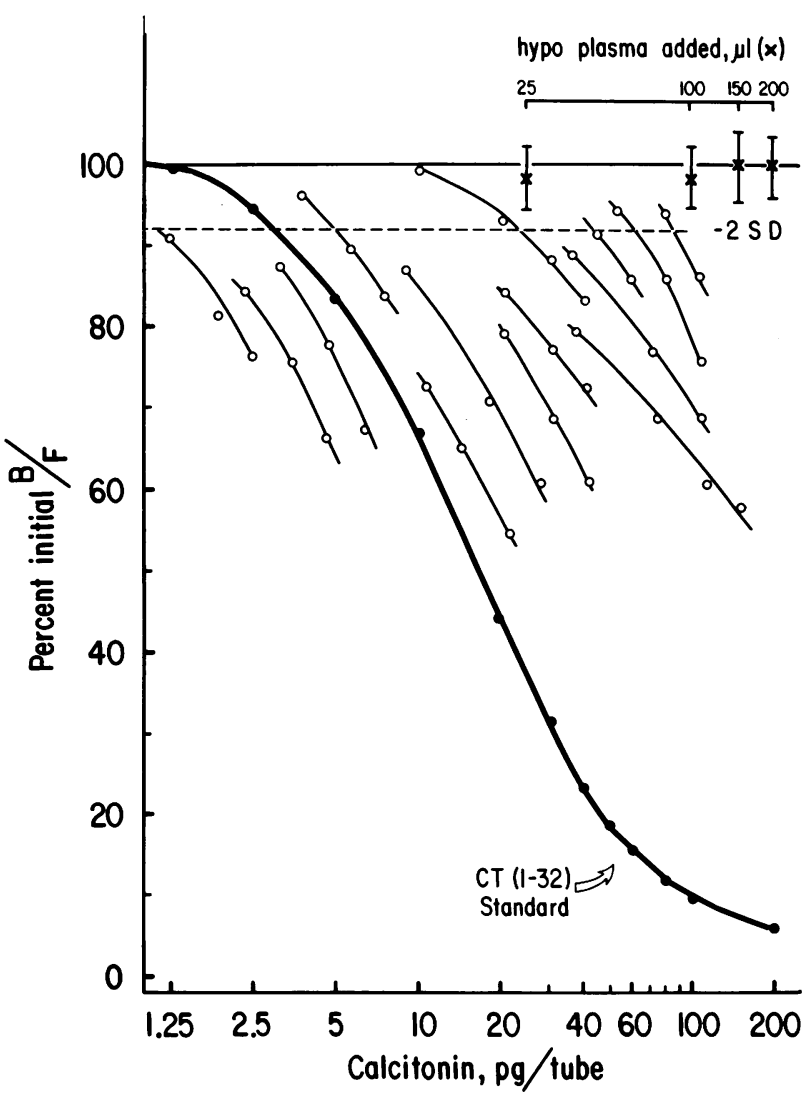

FIGURE 1 CT radioimmunoassay standard and sample curves. The standard curve $(0-0)$ is generated with synthetic CT monomer. Normal fasting plasma samples $(\mathrm{O} \bigcirc)$ were added at 200-, 150-, 100-, and 50- $\mu$ l volumes. "Hypo plasma" (mean \pm SD) refers to various additions of hypocalcitoninemic plasma. $-2 \mathrm{SD}(---)$ represents the mean $-2 \mathrm{SD}$ of the trace or initial $\mathrm{B} / \mathrm{F}$, which is the assay detection limit. Immunodilution curves, not shown here, for plasma from patients with medullary thyroid carcinoma, and from normal subjects given calcium or pentagastrin, were also parallel to the standard curve.

blood sampling at $0,1-2,10$, and $15 \mathrm{~min}$. There were no serious adverse reactions to any study. Blood samples were immediately chilled, and plasma separated from red cells within $4 \mathrm{~h}$. Plasma was stored at $-18^{\circ} \mathrm{C}$ for $<3 \mathrm{mo}$. No significant changes in iCT were observed in samples during this period, in contrast to the degradation of standard synthetic CT seen in hypocalcitoninemic plasma.

\section{Other methods}

Serum calcium was determined by atomic absorption spectroscopy (13), normal adult range $8.9-10.1 \mathrm{mg} / \mathrm{dl}$, and serum phosphorus by a colorimetric method (14), normal range 2.5$4.5 \mathrm{mg} / \mathrm{dl}$. Statistical analyses were performed in consultation with the Section of Medical Research Statistics, employing the $t$ test, rank sum, chi-square and median tests, and multivariate analyses where appropriate $(15,16)$. We calculated linear regression equations for individual calcium infusion data by the method of least squares (15). For purposes of data analysis, samples containing no detectable CT were assigned the value of the usual assay detection limit, $25 \mathrm{pg} / \mathrm{ml}$, unless otherwise specified.

\section{RESULTS}

\section{CT radioimmunoassay}

The absolute assay sensitivity ranged from 1.25 to 10 pg CT per tube, with virtually all assays capable of measuring $\leqq 5 \mathrm{pg}$ CT per tube or $\leqq 25 \mathrm{pg} / \mathrm{ml}$ of plasma. Immunodilution curves of 14 normal basal plasma samples were parallel to the curve produced by synthetic human CT monomer (Fig. 1). Immunodilution curves of normal plasma after calcium or pentagastrin, and from patients with medullary thyroid carcinoma were likewise parallel to the standard. Additions of 25-200 $\mu l$ of plasma from an athyreotic patient produced no nonspecific depression of $B / F$ (Fig. 1). Incubation of plasma samples at $20^{\circ} \mathrm{C}$ for up to $24 \mathrm{~h}$ caused no consistent decrease in endogenous iCT. The iCT concentration fell to undetectable levels during EDTAinduced hypocalcemia (basal, $28 \mathrm{pg} / \mathrm{ml}$ [ $80 \%$ of trace $\mathrm{B} / \mathrm{F}$ ] and after $1 \mathrm{~h}$ of EDTA, $<15 \mathrm{pg} / \mathrm{ml}$ [96\% of trace $\mathrm{B} / \mathrm{F}]$ ), and was undetectable in the 10 thyroidectomized patients.

Antiserum G 1701 recognized the amino acid sequence region 11-28 of the human CT sequence (Fig. 2 ). We emphasize that these specificity studies are indirect. Until direct inhibition of tracer binding can be demonstrated with currently unavailable CT peptide fragments such as $\mathrm{H}-11-17-\mathrm{OH}, \mathrm{H}-18-28-\mathrm{OH}$, and $\mathrm{H}-29-32-\mathrm{NH}_{2}$, we shall assign antiserum G 1701 a

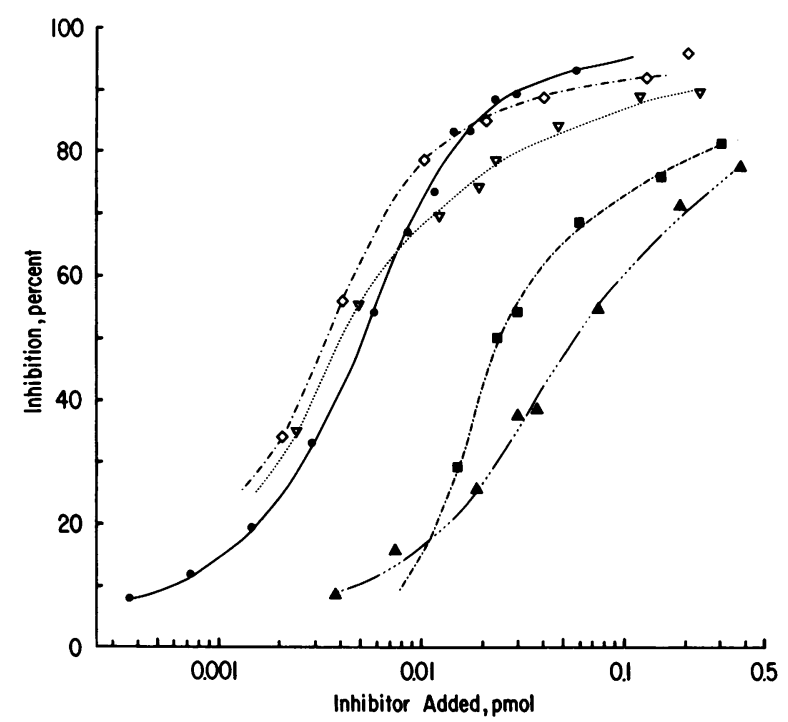

FIGURE 2 Inhibition of binding by $G 1701$ antiserum of ${ }^{131}$ I-labeled synthetic human CT by CT 1-32 (०- -0$)$, H-11-32- $\mathrm{NH}_{2}(\diamond-\cdot-\diamond)$, H-11-28-OH $(\nabla---\nabla)$, H-17$32-\mathrm{NH}_{2}(\square-\cdot-\square)$, and $\mathrm{H}-17-28-\mathrm{OH}(\Delta-\cdots-\Delta)$. The major immunochemical determinant appears to reside in the region of amino acid residues $11-28$. 


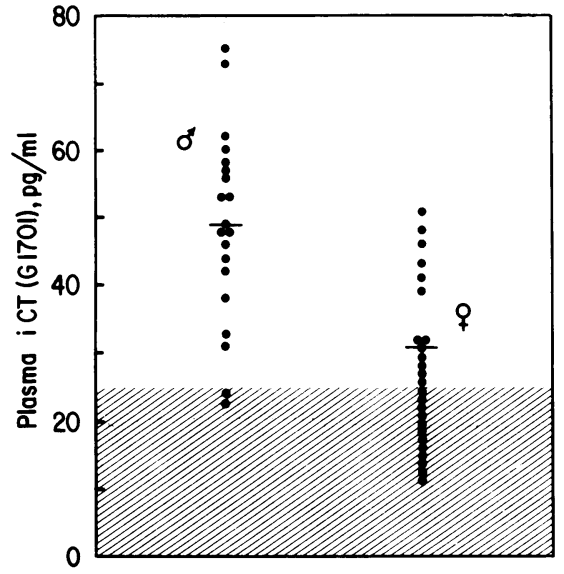

FIGURE 3 Basal iCT concentrations in 45 normal adults. Means for male $(\delta)$ and female ( $q$ ) values are shown by the horizontal bars. Points within the hatched area are below the assay detection limit $(25 \mathrm{pg} / \mathrm{ml})$. Values for women are significantly below those of the men $(P<0.001)$.

"central" sequence recognition (amino acid residues 11-28). Antiserum G 1701 showed no cross-reactivity with pentagastrin, salmon CT, porcine CT, secretin, or cholecystokinin-pancreozymin at $100 \mathrm{ng}$ /assay tube.

\section{Plasma CT concentrations}

Normal basal plasma samples. The mean basal iCT of males was $49 \mathrm{pg} / \mathrm{ml}$ (range, <25-73) and the mean basal iCT of females was $31 \mathrm{pg} / \mathrm{ml}$ (range, <25-51) (Fig. 3) The two groups are significantly different by the $t$ test $(P<0.001)$, the median test $(P<0.005)$, and the rank sum test $(P<0.01) .2$ of the 20 men $(10 \%)$ had undetectable iCT, but 12 of the 25 women $(48 \%)$ had undetectable iCT in the basal state. As we had found with an earlier assay $(17,18)$, there was no correlation of basal iCT with serum total calcium; we did not measure serum ionized calcium in these studies. Likewise, there was not a statistically significant correlation between basal serum phosphate and iCT concentrations.

Calcium infusion. Calcium infusion produced a linear increase of iCT (mean linear regression coefficient $[r] \pm \mathrm{SD}=0.95 \pm 0.06$ for absolute increase of $\mathrm{iCT}$ from basal/absolute increase of serum calcium from basal $[\Delta \mathrm{iCT} / \Delta \mathrm{Ca}])$ in 17 of the 20 male subjects $(85 \%)$ (Figs. 4a, 5); one man had undetectable iCT throughout the infusion, one was detectable but increased $<10$ $\mathrm{pg} / \mathrm{ml}$, and one subject's iCT increased $16 \mathrm{pg} / \mathrm{ml}$ by the 1 st $h$ but rose no further. The maximum iCT concentration achieved was $205 \mathrm{pg} / \mathrm{ml}$. The female subjects generally had lesser iCT responses to calcium than did the men (Figs. $4 a, 5)$ : only 14 of the 25 women $(56 \%)$ had linear increases of iCT (average $r \pm \mathrm{SD}=0.93$ $\pm 0.06)$, whereas a total of $11(44 \%)$ had no significant or detectable increase $\left(\chi^{2}, P=0.02\right)$. The peak iCT concentration achieved by males was $205 \mathrm{pg} / \mathrm{ml}$, and for women, $135 \mathrm{pg} / \mathrm{ml}$. The maximum responses $(\Delta \mathrm{iCT})$ of the men $(58 \pm 9 \mathrm{pg} / \mathrm{ml}$, mean $\pm \mathrm{SE})$ were significantly greater than those of the women $(25 \pm 6 \mathrm{pg} / \mathrm{ml})$ by $t$ test and rank sum $(P<0.01)$.

We analyzed the data from subjects having detectable iCT at all times, by multivariate analysis: here, the mean slope of $\Delta \mathrm{iCT}$ vs. time (or $\Delta \mathrm{Ca}$ ) of the females was less than that of the males, but not significantly $(P=0.09)$. However, the women had lower iCT values at all time points $(P=0.01)$. In another analysis, we assumed that subjects with no detectable iCT had the maximum possible response (iCT rising from 0 to 25 $\mathrm{pg} / \mathrm{ml}$ in $4 \mathrm{~h}$ ), slope $=25 / 4$. In this test, the mean iCT responses were not parallel $(P=0.012)$, and women had a significantly lower mean slope than did the men $(P=0.015)$. There was no significant effect of age on iCT response to calcium in either sex.
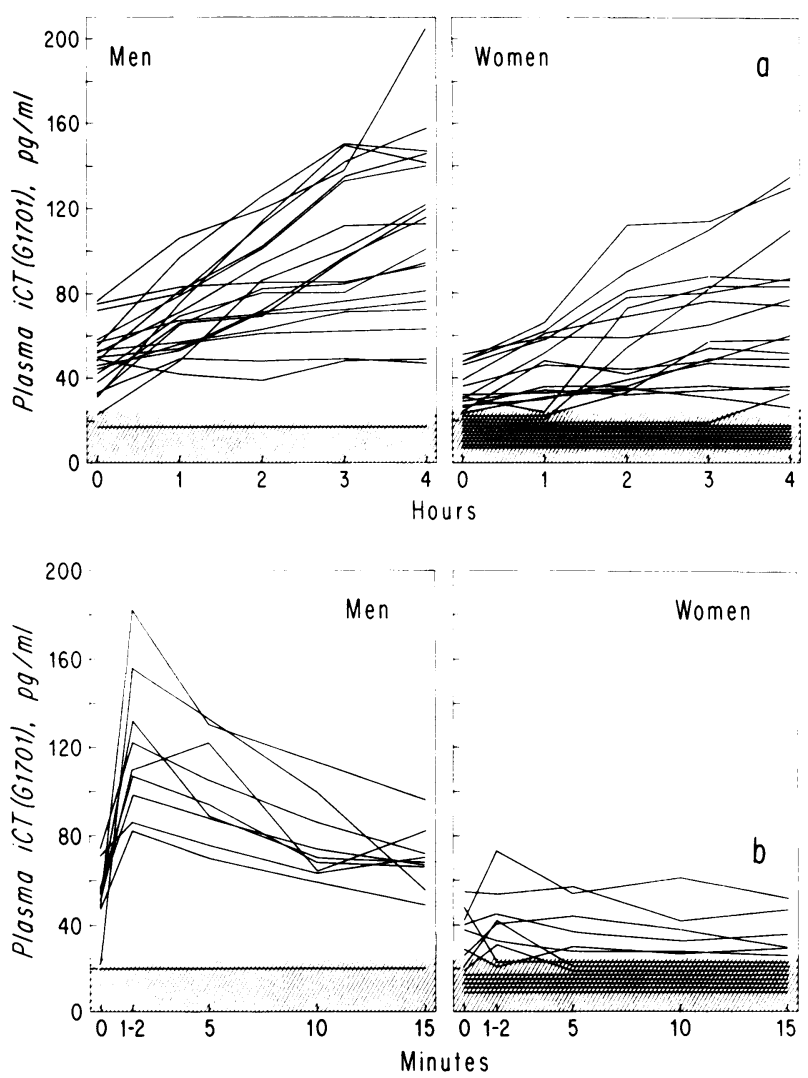

Figure 4 iCT during 4-h calcium infusion in 45 normal adults (a) and after i.v. pentagastrin injection in 25 normal adults (b). Values within the hatched areas were below the assay detection limits. Women had significantly lower iCT values and lesser responses to these two secretagogues than did men, by several statistical criteria. 


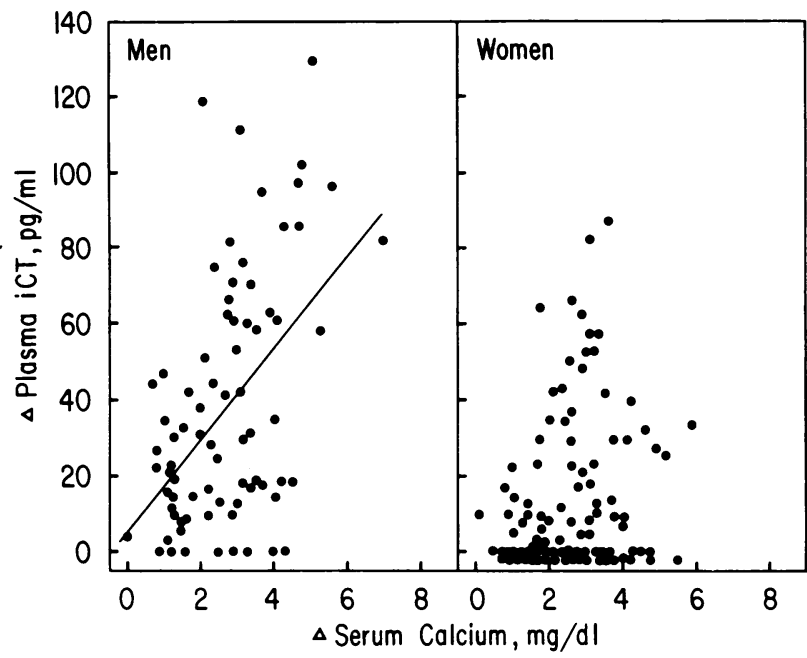

FIgUre 5 Calcium infusion in 45 normal subjects. Men, left panel; women, right panel. Increment in iCT $(\Delta \mathrm{iCT})$ plotted against increment in serum calcium $(\Delta \mathrm{Ca})$. Regressions were computed omitting data from "nonresponders" to avoid bias. The dramatic relation of $\Delta \mathrm{iCT}$ to $\Delta \mathrm{Ca}$ among the men is less apparent among the women. Men, $r=0.50, P<0.001$; women, $r=0.27, P<0.01$.

Serum calcium and phosphorus concentrations did not differ between the sexes before or during calcium infusion; likewise their absolute increases during calcium infusion were not significantly different.

Pentagastrin injection. The iCT responses of men to pentagastrin also exceeded those of the women (Fig. $4 \mathrm{~b})$. The maximum iCT achieved was $182 \mathrm{pg} / \mathrm{ml}$ in men and $73 \mathrm{pg} / \mathrm{ml}$ in women. Only 1 of the 10 male subjects failed to respond to pentagastrin (he also had no response to calcium infusion). By contrast, 5 of the 14 women had undetectable iCT throughout the study. Of the remainder, only one woman had an iCT increment of more than $20 \mathrm{pg} / \mathrm{ml}$. In general, those subjects who failed to respond to calcium also failed to respond to pentagastrin. These male-female differences are statistically significant $(P<0.001)$.

\section{DISCUSSION}

The radioimmunoassay we employed for the present studies is highly sensitive ( $\leq 25 \mathrm{pg} \mathrm{CT} / \mathrm{ml}$ unextracted plasma) and specific for human CT. CT concentrations are undetectable in the plasma of thyroidectomized patients, decrease during EDTA-induced hypocalcemia, and rise after administration of known CT secretagogues. Increases of $\mathrm{iCT}$ during calcium infusion are linearly related to $\Delta \mathrm{Ca}$. Normal basal and stimulated plasmas yield immunodilution curves parallel to synthetic standard. CT diluted in buffer $(0.25 \%$ bovine serum albumin) and hypocalcitoninemic plasma give superimposable standard curves, and "recovery" of CT added to plasma is complete from $200 \mathrm{pg} /$ tube to as little as $2.5 \mathrm{pg} /$ tube. We believe that these characteristics are ample validation of the assay (19), and justify our interpretation of the present data.

In this study, the lower iCT concentrations in women as compared with men were not predicted. However, the results of provocative tests and the statistical analyses leave little room for doubt that the differences are real. During induced hypercalcemia, nearly half of the women had minimal or undetectable increases in iCT, whereas 17 of 20 men showed dramatic increases in iCT. Even if one assumes that the women having no detectable iCT had the maximum possible responses to calcium, statistical analysis shows that the mean slope of CT response vs. time (or $\Delta \mathrm{Ca}$ ) is significantly lower for the women than for the men. Even more impressive was the failure of iCT to increase $(>20 \mathrm{pg} / \mathrm{ml})$ in response to pentagastrin administration in all but one women; by comparison, 8 of 10 men tested showed increases of iCT $>30 \mathrm{pg} / \mathrm{ml}$.

Silva et al. (3) reported that the highest iCT value recorded with their assay among 50 men was greater than the highest value in 17 women. Although they gave no statistical assessment to support a conclusion that women have lower iCT concentrations than men, the results appear consistent with ours. The same group has recently reported in an abstract (20) that women have lower urinary CT excretion than men, and lesser increases of urinary CT after a large oral calcium load. These results are again quite consistent with those in our present report.

Sex differences in circulating CT concentrations have been noted in nonhuman species. Deftos et al. (21) have shown bulls to have higher circulating CT concentrations than do cows. Boelkins and Kenny (22) showed that adult male Japanese quail have higher CT values (bioassay) than immature males, or females of any age; and that in contrast to male birds, females had no detectable increase in CT after calcium challenge (23). Different results have been reported in salmon (24), in which females have higher circulating iCT than males. The data of Samaan et al. (25) in man showed a decline in mean basal iCT values from infancy to adulthood, but we saw no such trend in basal or stimulated values over the age range of our subjects.

The physiologic significance of these results is unknown, but they may represent a valuable clue to a new and manipulatable varible in the pathogenesis of osteoporosis. Considering the high prevalence of significant bone loss in women after menopause, and the recent report that calcium infusion therapy of osteoporosis may be efficacious in men only (26), we propose that a lifelong relative deficiency of CT in some women may predispose to abnormal increases in bone resorp- 
tion. This may be of little importance until after the menopause (27), when the effect of estrogens in opposing parathyroid hormone-induced bone resorption is lost.

\section{ACKNOWLEDGMENTS}

We gratefully acknowledge the skillful technical assistance of Joan M. Larson, Christine M. Jerpbak, Lee Fast, and the Clinical Research Center staff; the secretarial assistance of Yvonne Shopteau; William F. Taylor, Ph.D., and Kenneth Offord, M.S., for statistical expertise; Doctors C. S. Anast, W. Rittel, and J. Stevens for materials; and the continuing advice and guidance of Dr. C. D. Arnaud.

This investigation was supported by Fellowship Award AM-00983, research grants CA-11911 and RR585 from the National Institutes of Health, U. S. Public Health Service, and the Mayo Foundation.

\section{REFERENCES}

1. Sherwood, L. M. 1968. Relative importance of parathyroid hormone and thyrocalcitonin in calcium homeostasis. N. Engl. J. Med. 278: 663-670.

2. Parthemore, J. G., and L. J. Deftos. 1975. The regulation of calcitonin in normal human plasma as assessed by immunoprecipitation and immunoextraction. J. Clin. Invest. 56: 835-841.

3. Silva, O. L., R. H. Snider, and K. L. Becker. 1974. Radioimmunoassay of calcitonin in human plasma. Clin. Chem. 20: 337-339.

4. Heynen, G., and P. Franchimont. 1974. Human calcitonin radioimmunoassay in normal and pathological conditions. Eur. J. Clin. Invest. 4: 213-222.

5. Rojanasathit, S., J. G. Haddad, J. Ladenson, L. Hillman, A. Ketupanya, and C. V. Rojanasathit. 1976. Characterization of a new human calcitonin (HCT) radioimmunoassay. Endocrinology. 98: 292A. (Abstr.)

6. Sizemore, G. W., and H. Heath III. 1975. Immunochemical heterogeneity of calcitonin in plasma of patients with medullary thyroid carcinoma. J. Clin. Invest. 55: 1111-1118.

7. Baylin, S. B., T. H. Hsu, and G. V. Foster. 1974. Degradation of calcitonin in plasma from patients with hypercalcemia. Endocrinology. 94: 214A. (Abstr.)

8. Arnaud, C. D., H. S. Tsao, and T. Littledike. 1971. Radioimmunoassay of human parathyroid hormone in serum. J. Clin. Invest. 50: 21-34.

9. Ferguson, A. J. 1965. Angular Correlation Methods in Gamma-Ray Spectroscopy. American Elsevier, New York. 103-106.

10. Deftos, L. J. 1974. Parathyroid Hormone. In Methods of
Hormone Radioimmunoassay. B. M. Jaffe and H. R. Behrman, editors. Academic Press Inc., New York. 231-247.

11. Deftos, L. J., A. E. Bury, J. F. Habener, F. R. Singer, and J. T. Potts, Jr. 1971. Immunoassay for human calcitonin. II. Clinical studies. Metab. Clin. Exp. 20: 11291137.

12. Habener, J. F., F. R. Singer, L. J. Deftos, and J. T. Potts, Jr. 1972. Immunological stability of calcitonin in plasma. Endocrinology. 90: 952-960.

13. Slavin, W. 1968. Atomic Absorption Spectroscopy. WileyInterscience Div., John Wiley \& Sons, New York.

14. Fiske, C. H., and Y. Subbarow, 1925. Colorimetric determination of phosphorus. J. Biol. Chem. 66: 375-400.

15. Dixon, W. J., and F. J. Massey, Jr. 1969. Introduction to Statistical Analysis. McGraw-Hill Book Co., New York. 3rd edition.

16. Morrison, D. F. 1967. Multivariate Statistical Methods. McGraw-Hill Book Co., New York. 141-148.

17. Sizemore, G. W., J. Leffler, J. Fischer, S. Oldham, R. Goldsmith, and C. D. Arnaud. 1972. Physiological aspects of human calcitonin secretion. Clin. Res. 20: 441 (Abstr.)

18. Sizemore, G. W., C. D. Arnaud, and R. Goldsmith. 1973. Calcitonin, parathyroid hormone, and calcium homeostasis in normal man. J. Bone Jt. Surg. Am. Vol. 55: 660A. (Abstr.)

19. Yalow, R. S., and S. A. Berson. 1971. Problems of validation of radioimmunoassays. In Principles of Competitive Protein-Binding Assays. W. D. Odell and W. H. Daughaday, editors. J. B. Lippincott, Philadelphia. 374400.

20. Becker, K. L., O. L. Silva, R. H. Snider, and C. F. Moore. 1977. A physiologic role of calcitonin in man: response to oral calcium. Clin. Res. 25: 534A. (Abstr.)

21. Deftos, L. J., J. F. Habener, G. P. Mayer, A. E. Bury, and J. T. Potts, Jr. 1972. Radioimmunoassay for bovine calcitonin. J. Lab. Clin. Med. 79: 480-490.

22. Boelkins, J. N., and A. D. Kenny. 1973. Plasma calcitonin levels in Japanese quail. Endocrinology. 92: 17541760.

23. Boelkins, J. N. 1971. Plasma calcitonin in avian species. Ph.D. thesis, University of Missouri, Columbia, Mo. 50.

24. Watts, E. G., D. H. Copp, and L. J. Deftos. 1975. Changes in plasma calcitonin and calcium during the migration of salmon. Endocrinology. 96: 214-218.

25. Samaan, N. A., G. D. Anderson, and M. E. Adam-Mayne. 1975. Immunoreactive calcitonin in the mother, neonate, child and adult. Am. J. Obstet. Gynecol. 121: 622-625.

26. Walton, J., M. Dominguez, and F. C. Bartter. 1975. Effects of calcium infusions in patients with postmenopausal osteoporosis. Metab. Clin. Exp. 24: 849-854.

27. Riggs, B. L., R. J. Ryan, H. W. Wahner, N.-S. Jiang, and V. R. Mattox. 1973. Serum concentrations of estrogen, testosterone, and gonadotropins in osteoporotic and nonosteoporotic postmenopausal women. J. Clin. Endocrinol. Metab. 36: 1097-1099. 